\title{
Correlation between plasma fibrin-fibrinogen degradation product values and CT findings in head injury
}

\author{
SHINSUKE UEDA, KAZUHIKO FUJITSU, HIDEYO FUJINO, TSUNEMI SEKINO, \\ TAKEO KUWABARA
}

From the Department of Neurosurgery, Yokohama City University, School of Medicine, Yokohama, Japan

SUMMARY Plasma fibrin/fibrinogen degradation product (FDP) determinations and CT scans were performed in 26 patients on the first, third, and seventh day after head injury. Plasma FDP concentrations were increased in the patients with cerebral contusion shown on CT scans, while the plasma FDP values were normal in the patients with various sized epidural haematomas. Furthermore, the plasma FDP elevation appeared to be more marked and more prolonged in the patients with severe contusion than in those with mild contusion. These findings suggest that the degree of the increase in plasma FDP is proportional to the amount of brain tissue destruction.

Coagulation abnormalities after severe head injury have been reported with increasing frequency over the past ten years. Among these abnormalities, disseminated intravascular coagulation (DIC) is the most severe complication and often results in poor outcome. Coagulation abnormalities not so severe as disseminated intravascular coagulation are also found in head injured patients. Fibrin/fibrinogen degradation product (FDP) measurement is one of the most popular coagulation tests, and increased FDP in the plasma indicates accelerated fibrinolysis. We studied the serial plasma FDP values in 26 head injured patients classified into six groups on the basis of serial CT findings.

\section{Clinical materials and methods}

The 26 patients studied were admitted within 6 hours of head injury. In all patients the injuries were caused by traffic accident. Age distribution ranged from 10 to 68 years. There were 18 men and eight women. CT scans were carried out as soon as possible after admission, and consequently all of the initial CT scans were performed within 12 hours of the head injury. In addition to the CT scanning, plasma FDP concentration was measured by the method of FDPL (Latex agglutination test).' The patients

Address for reprint requests: Shinsuke Ueda M.D., Department of Neurosurgery, Nishiarai hospital, 5-7-14 Nishiarai honcho, Adachi-ku, Tokyo 123, Japan.

Received 21 March 1984 and in revised form 22 June 1984. Accepted 5 June 1984 who had other severe trauma (haemothorax, major bonê fracture, etc) were excluded from this study. CT scans were normal in six patients. Subdural effusion was observed i $\vec{p}$ three patients, epidural haematoma in five and cerebraf contusion in 12 . Of all patients with epidural haematomas two had a large haematoma showing marked mass effect on CT scans. Craniotomy was performed for evacuation haematoma in these patients with large epiduraf. $\overrightarrow{0}$ haematoma. Of all patients with cerebral contusion, seve had mild and localised contusion and five had severe and extensive contusion. All of the five patients with severe contusion underwent decompressive craniectomy. The other patients were managed only with medical decompression (glycerol, steroids), mild dehydration, and sedation. Serial FDP measurement and CT scans were routinely performed on Days 3 and 7 after injury in all but one patient who died on Day 4 . We divided all 26 patients into six groups according to CT findings: normal, subdural effusion, small epidural haematoma, large epidural haematoma, mild contusion, and severe contusion. In each group the relationships between CT findings and FDP values were studied serially. Furthermore, in order to investigate the correlation between plasma FDP level and clinical conscious level the patients were divided into three groups according to their level of consciousness on admission: (1) clear consciousness; (2) confusion; and (3) semicoma or coma.

\section{Results}

Six patients with normal CT scans showed normal plasma FDP values (normal range: $<10 \mu \mathrm{g} / \mathrm{ml}$ ) on the first, third and seventh day of injury. In the three patients with subdural effusion the abnormality of 


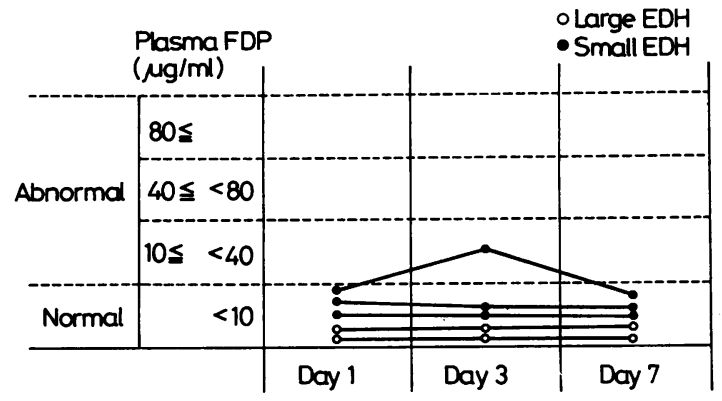

Fig 1 Plasma FDP values of three patients with small epidural hematoma and two patients with large epidural hematoma on Day 1, Day 3 and Day 7.

plasma FDP was found in one on admission and in another on the seventh day. In four out of five patients with epidural haematoma, plasma FDP values were within normal limits on the first, third and seventh day irrespective of the size of haematoma. Only one patient with small epidural haematoma showed slight FDP elevation (fig 1). No remarkable changes were detected on serial CT scans in three patients with small epidural haematoma. In two patients with large epidural haematoma (operated on the first day) CT scans showed brain oedema in the third and seventh day. Among seven patients with mild contusion, plasma FDP levels were slightly increased $(10 \leqslant,<40 \mu \mathrm{g} / \mathrm{ml})$ on the day of admission in four patients, on the third day in one patient, and on the seventh day in two patients. In contrast to these patients with mild contusion, of five patients with severe contusion plasma FDP values were abnormal in three patients on Day 1, and in all patients on Day 3 and Day 7 (table 1). The elevation of plasma FDP appeared more marked and more prolonged in severe contusion than in mild one (figs 2 and 3 ). One patient with severe cerebral contusion who showed markedly elevated FDP values (above $80 \mu \mathrm{g} / \mathrm{ml}$ on the first and third day) died on the fourth day of injury. The high density area of the contusion on CT scans gradually decreased in the patients with mild contusion. On the other hand,

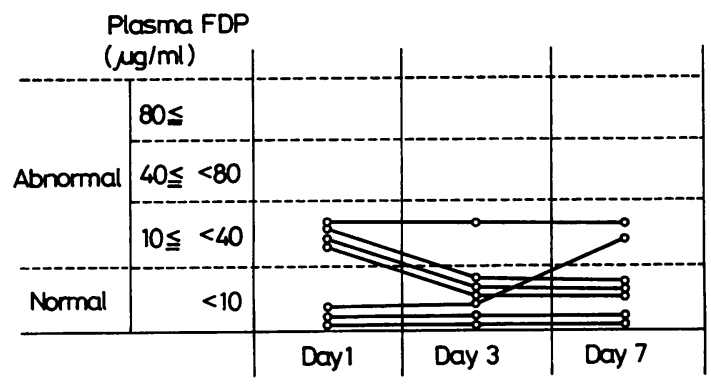

Fig 2 Plasma FDP values of seven patients with mild contusion on Day 1, Day 3 and Day 7.

serial CT scans of the patients with severe contusion did not show remarkable change in the high density area of the contusion, although varying degrees of brain oedema were noted on the third day.

The result of correlation between conscious levels and CT findings also appeared to show that the patients with contusion were less conscious than the patients with epidural haematoma (table 2). On admission plasma FDP level was abnormal in none of the seven patients with clear consciousness, in five of the 16 patients with confusion and in two of the three semicomatose or comatose patients (table 2).

\section{Discussion}

There have been a considerable number of reports on the coagulation abnormalities developing in severe head injury. Even disseminated intravascular coagulation has been sometimes documented in patients after severe head injury. ${ }^{23578}$ However abnormalities in coagulation tests were only infrequently detected in the whole population of head injured patients. ${ }^{39}$ The haematological mechanism of this abnormal coagulation has been explained by the release of tissue thromboplastin from the brain tissue, which is well known to be abundant in tissue thromboplastin.' From this point of view, J. Japp van der Sande et al had suggested that coagulation abnormalities were caused by the brain tissue destruction rather than by brain compression. ${ }^{9}$ The pre-

Table 1 Number of cases with increased fibrin/fibrinogen degradation products (FDP)

\begin{tabular}{|c|c|c|c|c|}
\hline$C T$ findings and no of cases & & Day 1 & Day 3 & Day 7 \\
\hline $\begin{array}{l}\text { Normal } \\
\text { Subdural Effusion } \\
\text { Small EDH } \\
\text { Large EDH } \\
\text { Mild Contusion } \\
\text { Severe Contusion }\end{array}$ & $\begin{array}{l}6 \\
3 \\
3 \\
2 \\
7 \\
5\end{array}$ & $\begin{array}{l}0 \\
1 \\
0 \\
0 \\
4(57 \%) \\
3(60 \%)\end{array}$ & $\begin{array}{l}0 \\
0 \\
1(33 \%) \\
0 \\
1(14 \%) \\
5(100 \%)\end{array}$ & $\begin{array}{l}0 \\
1 \\
0 \\
0 \\
2(29 \%) \\
4(100 \%)^{*}\end{array}$ \\
\hline
\end{tabular}

EDH: Epidural haematoma

${ }^{*}$ : One patient died on Day 4 
Table 2 Level of consciousness, CT findings and the number of cases with increased FDP on admission

\begin{tabular}{|c|c|c|c|c|}
\hline$C T$ findings and no of cases & & Clear consciousness & Confusion & $\begin{array}{l}\text { Semicoma } \\
\text { or coma }\end{array}$ \\
\hline $\begin{array}{l}\text { Normal } \\
\text { Subdural Effusion } \\
\text { Small EDH } \\
\text { Large EDH } \\
\text { Mild Contusion } \\
\text { Severe Contusion } \\
\text { Total }\end{array}$ & $\begin{array}{r}6 \\
3 \\
3 \\
2 \\
7 \\
5 \\
26\end{array}$ & $\begin{array}{l}5(0)^{*} \\
0 \\
2(0) \\
0 \\
0 \\
0 \\
7(0)\end{array}$ & $\begin{array}{r}1(0) \\
3(0) \\
1(0) \\
2(0) \\
7(4) \\
2(1) \\
16(5)\end{array}$ & $\begin{array}{l}0 \\
0 \\
0 \\
0 \\
0 \\
3(2) \\
3(2)\end{array}$ \\
\hline
\end{tabular}

*The number in parenthesis indicates the number of cases with abnormal plasma FDP levels.

sent study also indicated that the elevated values of FDP were detected mainly in brain destruction (contusion) and not in brain compression (epidural haematoma). These results support the hypothesis of the brain tissue thromboplastin release into general circulation. However, disseminated intravascular coagulation was not found in this study. This fact could be explained by the possible occurrence of "local" disseminated intravascular coagulation in contused brain tissue, which is detected by the increase of plasma FDP. In this study plasma FDP values were well correlated with the extent of the brain destruction. Plasma FDP elevation on Day 3 and Day 7 in the patients with severe cerebral contusion appeared to be the result of prolonged "local" disseminated intravascular coagulation in extensively contused brain tissue. Therefore, only external decompression craniectomy was not sufficient to treat the patients with severe cerebral contusion and the contused brain tissue should have been removed.

In this study plasma FDP levels were found to be correlated with the level of consciousness to some extent. However, the correlation between plasma FDP level and level of consciousness cannot be concluded positively, because the numbers in each group are small.

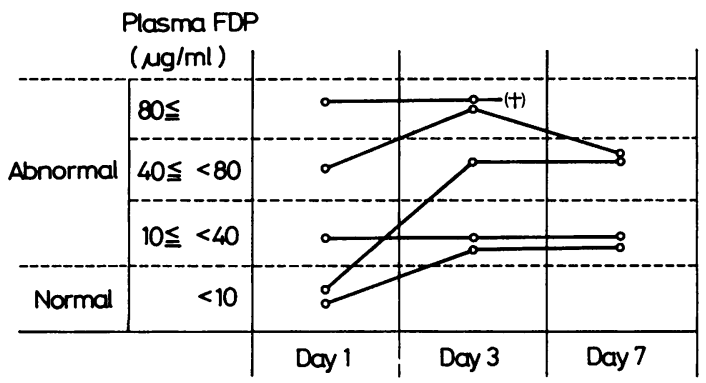

Fig 3 Plasma FDP values of five patients with severe contusion on Day 1, Day 3 and Day 7. $\dagger$ : died on Day 4.
Clinical findings and other coagulation tests (platelet count, prothrombin time, partial thrombin time, fibrinogen level etc) are also required to support further the hypothesis of "local" disseminated intravascular coagulation. Serial CT scans ${ }^{10}$ and clinical findings ${ }^{46}$ are principally important for evaluating the prognostic features in head injured patients. However, this study suggested that plasma FDP measurement was also of some value in determining the extent of contusion and forecasting the final outcome from head injury.

\section{References}

${ }^{1}$ Astrup T. Assay and content of tissue thromboplastin if different organs. Thrombos Diathes Haemorth $1965 ; 14: 401-16$.

${ }^{2}$ Drayer BP, Poser CM. Disseminated intravascula coagulation and head trauma. JAMA 1975;231:174 5.

${ }^{3}$ Goodnight SH, Kenoyer G, Rapaport SI, Patch MJ, Lee JA, Kurze T. Defibrination after brain-tissue destruction, a serious complication of head injury. $N$ Engl J Med 1974;290:1043-7.

${ }^{4}$ Jennet B, Teasdale G, Braakman R, Minderhoud J, Heiden J, Kurze T. Prognosis of patients with severe head injury. Neurosurgery 1979;4:283-9.

${ }^{5}$ Keimowitz RM, Annis BL. Disseminated intravascular coagulation associated with massive brain injury. $J$ Neurosurg 1973;39:178-80.

${ }^{6}$ Levati A, Farina ML, Vecchi G, Rossanda M, Marrubini MB. Prognosis of severe head injuries. J Neurosurg 1982;57:779-83.

${ }^{7}$ McGauley JL, Miller CA, Penner JA. Diagnosis and treatment of diffuse intravascular coagulation following cerebral trauma. J Neurosurg 1975;43:374-6.

${ }^{8}$ Pondaag W. Disseminated intravascular coagulation related to outcome in head injury. Acta Neurochirurgica, Suppl 1979;28:98-102.

' Van der Sande JJ, Veltkamp JJ, Boekiiout-Mussert RJ, Bouwhuis-Hoogerwerf ML. Head injury and coagulation disorders. J Neurosurg 1978;49:357-65.

10 Yamaura A, Nakamura T, Ono J, et al. Prognotic value of CT in head injuries. Neurol Med Chir (Tokyo) 1981;21:685-96. 